\title{
ANALYSIS OF EDUCATION VALUE OF CHARACTER IN NOVEL 5 CM BY DONNY DHIRGANTORO
}

\author{
Rut Leni Natalia br Sembiring1, Emma Martina br pakpahan² \\ 1,2 UNIVERSITAS PRIMA INDONESIA \\ ${ }^{1}$ rutlenisembiring@gmail, ${ }^{2}$ emmathina@gmail.com
}

\begin{abstract}
Character education is closely related to moral education, which is to shape and train individual abilities continuously for self-improvement towards a better life. Novel is a literary work that can convey the values of character education. The research aims to analyzing the values of character education in the novel $5 \mathrm{~cm}$ by Donny dhirgantoro. This research is a qualitative study using a descriptive design method. the data analysis technique by reading the entire data, analyzing the data in more detail and restating the data by described and interpreting the data. The result of this study are the value of character education contained in the novel " $5 \mathrm{~cm}$ " by Donny Dhirgantoro, namely, religious, hard work, love to read, friendly and communicative, social care, and love the homeland.
\end{abstract}

Keywords: Value, Character Education, Novel

\section{INTRODUCTION}

Character is human behavior that is related to God Almighty, fellow humans, the environment, and the nationality which is manifested in attitudes, actions, and words based on norms, prevailing in society. Character can also be interpreted as a good sign or characteristic in all situations of life (Sudrajat, 2011). The task of shaping character carried out by educational institutions collides with realities of life at the moment. Easy access to the media internet, which means easy access to the positive and negative sides, is the toughest challenge for educational institutions. This maturity in terms of age and emotions makes students easily lured into wrong social circles. This condition triggers the fall of character education, values instilled in the students. According to (Lickona, 2009) another part of the problem of children is the mass media and the environment which adversely affect children's live.

Depart from the problem, planting the value of character education is very important to build the character of the nation's next generation. From character education, children will be shaped and taught to become human beings who have positive characters such as wisdom, spirituality, honesty, responsibility, and respect for others. Character education is a national movement that creates schools as places to educate young generation to be responsible, good attitude and care for others by exemplifying and teaching good character through applied universal values (Adams, 2011) . In implementation of the character education at schools, every stakeholder of learning must be involved in the process, including the education components, namely curriculum, learning, and evaluation, process, quality of relationships, handling or management of learning, use of facilities and performance of each school component (Agung, 2018).

The inculcation of character education values can not only be done through educational institutions, but also through literary works. Novel is one of the literary works that can be used a medium for understanding the values of character education (Suryaman, 2010). Reading and learning novel are able to provide good benefits to readers. The readers can find out the meaning 
of the words contained in it can convey social phenomena that have positive values and can be used as a reference example that can influence the development of a person's positive attitude. Based on the above statement, the researchers is interested in analyzing the novel $5 \mathrm{~cm}$ by Donny Dhirgantoro. This novel tells about the journey of 5 friends namely Arial, Riani, Genta, Ian, and Zafran, on an adventure to mount Mahameru. This novel is good to using as a medium of learning in schools. Because in this novel contains the value character edication, namely religious, hard work, love to read, friendly and communicative, social care, and love the homeland.that is manifested in every event and personality of the character in the novel. This research is expected can help the younger generation in shaping. With this research the authors hope that the younger generation can understand and apply the character education values contained in the novel in everyday life.

\section{METHOD}

The study uses is a qualitative descriptive study. According to (Bogdan , R , \& Biklen, 1998) qualitative research is a research procedure that produces descriptive data that is closely related to the attitudes of the people being observed. Descriptive design research is used to describe the result of the analysis character education values and moral messages contained in the novel $5 \mathrm{~cm}$ by Donny Dhirgantoro.

The source of the data in this research is the Novel $5 \mathrm{~cm}$ by Donny Dhirghantoro first published in 2005 by the publisher PT Grasindo. The main instrument in this research is the researcher herself. Researchers write down and analyzing data during the study to collect data such as quotes obtained from novel texts. Then researchers themselves processed and analyzing the data in detail. Data collected in the following ways, 1. Researcher reads and understands the contents of the novel repeatedly, 2. Researcher write down every word or sentence that contains character education value. And then 3 . Researcher concluded that the Moral message contained in the novel. the data analysis technique by reading the entire data, analyzing the data in more detail and restating the data by described and interpreting the data.

\section{RESULTS AND DISCUSSION}

\section{Results}

The result of the study achieved after critical analysis, with observation of the story carried out, namely, the novel " $5 \mathrm{~cm}$ " by Donny Dhirgantoro.

Table 1. Characters and Characterization

\begin{tabular}{cl}
\hline Characters & \multicolumn{1}{c}{ Characterizations } \\
\hline Arial & $\begin{array}{l}\text { He is a simple person, but he takes pride in all of hanging out } \\
\text { because he is the only one who can be calm, smiles a lot and } \\
\text { rarely makes. }\end{array}$ \\
\hline Riani & $\begin{array}{l}\text { Riani is a smart girl. Because of that he is always active in } \\
\text { organizations on campus. He has dreams of working on tv. } \\
\text { herefore he has studying broadcasting. }\end{array}$ \\
\hline Zafran & $\begin{array}{l}\text { He is a very fond of poetry. Every moment he always took the } \\
\text { poetry. Besides that he is also a band vocalist who always } \\
\text { changes personnel, character zafran in the novel } 5 \text { cm is have a } \\
\text { good attitude and friendly. }\end{array}$ \\
\hline
\end{tabular}




\begin{tabular}{cl}
\hline Genta & $\begin{array}{l}\text { He is a hard worker, has an optimistic attitude and always has } \\
\text { creative ideas in his work. Character genta in novel } 5 \mathrm{~cm} \text { is a wise } \\
\text { man in any case. }\end{array}$ \\
\hline Ian & $\begin{array}{l}\text { Character Ian in the novel is very friendly and easy to get along } \\
\text { with anyone. The four friends really care about Ian who has a } \\
\text { large body and great sense of humor. }\end{array}$
\end{tabular}

\section{Discussion}

\section{Religious}

A good literary work is a literary work that has a message or values that can provide knowlwdge and instruction to its readers, One of these values is religious value (Novianti \& Munir, 2017). Religious is a character value that reflects human relationship with god. This character believes in the presence of god, so that human show behavior and thoughts based on their divine or religious values. There are several religious indicators found in the novel $5 \mathrm{~cm}$ as follows:

a. Pray

Praying is a form of worship performed by humans to Allah SWT. In order to be given ease and smoothness in living life. Praying means that humans always need help from God. In the novel $5 \mathrm{~cm}$ activities related to prayer are as follows.

"Genta heard daniek explanation became silent, staring at the warm afternoon sun. Slowly he glanced at the faces of his friends one by one, still staring blankly at the abyss right beside them. Inner Genta also prayed, "Ya.. Allah.... save them my friends. Everything that happens is your will all that is alive will come back to you. I leave it all to your majesty" (5cm: 212$)$

In this quotation, the activity of prayer is shown by genta. when he saw the worried of his friend after listening to daniek story. He lost his best friends while climbing in semeru. That's when genta surrendered and prayed for the safety of his friends to the almighty.

a. Be grateful

Grateful is the attitude of a human being to accept everything that Allah SWT has given. Grateful is able to motivate people to always think positively on all the grace and goodness of God. Whether in any condition that happens, humans are taught to be grateful. In this novel, an attitude of grateful is shown in the following conversation.

"But I'm sure, there must be something certain...that can't be bargained which even Albert Einstein can't explain." All the human children looked up at the blue sky above Ranu Kumbolo. Smile at each other.

"Yes, up there is one thing for sure"

"Definitely back to the one up there"

The wind caressing their faces gently accompanies the hearts of those that pray and give thanks.

"A human who doesn't believe in God is the same as a human that doesn't have dreams" (5cm: 278)

\section{Hard Work}

Hard work is an action which shows orderly behavior and complies with various rules and regulation (Wibowo, 2017) Hard work is an activity that is carried out seriously to achieve the 
desired target. The character of a hard worker always prioritizes satisfaction in every activity that is carried out so as to encourage someone to do their best to get maximum results.

a. Creative

Creative is a person's ability to create new ideas and concepts. A creative person tries to show new things that others sometimes unthinkable. In the novel $5 \mathrm{~cm}$ novel, genta shows a creative attitude in the following quote:

"Everyone is satisfied, man," said genta very happy

"yes... I didn't expect it, Ta. whereas at first we were very pessimistic."

"you're a pessimistic. I've never."

"Yes. you crazy. I think first no one wanted to participate in a computer exhibition using this jungle adventure nuance. How do you come up with an idea like that?"

"Well, the idea comes when you are pensive. The point is that when people use computers, they are adventure everywhere, between being on the internet or doing something. He's on an adventure, trying to create something new, something else himself." (5cm: 137)

Genta create a computer exhibition design idea with the nuance jungle adventure that seemed unique. But according to Genta, this in an unusual idea because of that he dared to make new innovation, even his co-worker firman did not expect that his creative idea would be successful in making his clients satisfied with his work.

b. Never give up

Never give up is the attitude of an individual who tries not to be Discourage in dealing with problems. this attitude of confidence and hard work. In novel $5 \mathrm{~cm}$ this attitude shown by Ian as follows:

"never what, Ian?"

"never give up sir."

"what?" the lecturer said a little loudly and glared at Ian.

"never ... give up sir..." His feelings felt different, his spirits returned.

"Good afternoon, Ian. You can definitely finish it in two months "the lecturer stood up and with a smile let Ian out of the room. "later you will come with a completed questionnaire. I am sure with you." After leaving the room, Ian suddenly felt relieved. "I never want to give up" $(5 \mathrm{~cm}: 126-127)$.

The lecturer assured Ian not to desperate because of failing research at a company. The lecturer gave Ian confidence that when there was a problem he had to get up, try again and never give up.

\section{Love to read}

Love to read is an activity that is preferred by an individual to deepen and improve knowledge. Diligently reading can add broad knowledge and insight. This reading attitude must be instilled in students because the learning process is based on reading ability (Umam, 2013). The reading habit is shown by the character Ian in the following quote:

"At night, while resting Ian reads reference books that are connected to his thesis. Tired of reading in bed, Ian moved to the balcony of his house. There Ian read again, read again, and read again, amazed by the various complex molecules flying through his mind. What he's never known. Ian came to know. Ian paused for a few moments and wrote a small note on HVS paper, and read again, read again. Ian had in mind, it's only two months from his trial, after that he graduate." (5cm: 113$)$

Ian is very excited to read the reference book for his thesis. because to do the thesis he must have more knowledge. so that his wish to pass immediately is achieved. 


\section{Social care}

Social care is a feeling responsible for the difficulties faced by others which someone helps to do something to overcome them (Tabi' in, 2017). A social care attitude is manifested in concrete action that require each individual to pay attention to the environment in which they live and society. In the novel $5 \mathrm{~cm}$, social care is shown by the character dinda as f1ollows:

"Mbok I give more money. But tomorrow Mbok promises not go to the market looking for used cardboard box, Mbok just sleep at home. promise yes, mbok!" dinda said

Mbok saw fifty thousand rupiah in his hand, his eyes enlarged and brought his hand closer to his nose, "Alhamdullilah Gusti... Alhamdullilah." (5cm:176)

Mbok is almost 60 years old working hard to earn a living until the night. Mbok tells them from the evening until the night he was selling rice packs, after that the next morning, Mbok looks for used cardboard box to be sold again.

5. Friendly and communicative

Friendly and communicative are attitudes that encourage good relations between an individual and another individual. A friendly attitude makes someone acceptable by others, while communicative makes someone easy to understand in conveying his thought to others. This attitude is shown by Ian and daniek in the following conversation:

"Mas, sorry, mas, I just want to say, your camera is tightly wrapped to keep it warm so that the light meter won't be damaged. The Nikon f4 is a little sensitive." Suddenly, one of the jeep passengers with the appearance of a student, a square face with a thin beard, with an orange slayer and black glasses rebuked Ian.

"Oh is that so, mas? Why?"

"It will be cold upstairs. Last year my light meter was broken, it was cold," replied the orange slayer, showing the camera hanging from his neck. Ian saw the black canon EOS hanging.

"Thank you, mas...for the advice."

"The orange slayer smiled kindly, "you're welcome."

"Mas, where did you come from?" asked Ian

"I'm from Surabaya...," he replied and then mentioned one of the famous technology campuse in Surabaya. "Daniek"

"Hah? Is there a relationship with Daniek G Sukarya?"

"Ian mentioned one famous nature photographer in Indonesia."

"No, my real name is Danie Kurnianto. Just to be cool, mas, I'm an admirer of Daniek G sukarya." Daniek answered Ian question with a smile. (5cm: 208)

From the conversation daniek and Ian have a friendly and communicative character. Daniek, dared to give advice to Ian, someone he just met, so that the light meter would not be damaged, which made Ian respond in a friendly manner thus supporting their conversation.

\section{Love the homeland.}

Love the homeland is an expression of the pride and dedication of an individual to his country and nation. This attitude is reflected in the behavior and actions that show loyalty and concern for their homeland. This attitude is very important to instill in student so that they get to know their nation and state. In the novel $5 \mathrm{~cm}$ this attitude is shown in the following quote:

"A face they had once known appeared to be one of the Flag bearers. The peak of mahameru is still in silence. The sound of the rope hoisting the flag on the bamboo pole was clearly heard. Until finally the dwi warna widened gallantly.

Srrt...bhet!

Flag ... ready! 
"For the raised flag, Hand salute..." A loud scream broke the silence of the peak of mahameru. All mountaineers simultaneously salute in silence, the sound of friction of their clothes while saluting the motion is heard in unison." (5cm: 345$)$

Coinciding on the seventeenth of August, the mountaineers perform the Indonesian Independence Day ceremony in a very beautiful place that is mount Mahameru. Their passion and struggle prove love the homeland.

The moral message that can be taken from the story of the novel $5 \mathrm{~cm}$ is:

This novel reminds us of friendship that believes in the power of dreams and attitudes of love the homeland. From their friendship we can learn to respect each other's differences of opinion and solve problems together. To manifest dreams and goals, we must have the beliefs that we can achieve them. As philosophized in the novel $5 \mathrm{~cm}$ "all your beliefs and dreams, don't put them on your forehead, but let them hang 5 centimeters in front of your forehead" which means everything you dream about don't take it out of your sight but let it hang on your sight so you can see it every day and believe that you can make it happen.

\section{CONCLUSION}

After analyzing the value of character education values in the novel $5 \mathrm{~cm}$ by Donny Dhirghantoro, it can be concluded as follows: the value of religious character education includes indicators of prayer and be grateful, the value of education for hard work includes creative and never give up, and the last is the vaslue of character education love to read, friendly and communicative, social care, and love the homeland. All the character education values obtained from the novel $5 \mathrm{~cm}$ novel are positive values that are good to build student character in everyday life.

\section{ACKNOWLEDGMENTS}

The writers would like to say the biggest thanks to IKIP Siliwangi which has given the chance to publish this article. The last but not least, the writers also say thanks to blind reviewer who reviews this article as well as to the editorial team so this article may be published perfectly. This reseach is a requirement to complete the English Language of Literature Study Programs, Faculty of Teacher Training and Education, Prima Indonesia University.

\section{REFERENCES}

Adams, A. (2011). the Need for Character Education. International Journal of Social Sciences and Humanity Studies, 3(2), 23-32.

Agung, L. (2018). Character Education Integration in Social Studies Learning. Historia: Jurnal Pendidik Dan Peneliti Sejarah, 12(2), 394-395. https://doi.org/10.17509/historia.v12i2.12111

Bogdan , R , \& Biklen, S. . (1998). Qualitative Research For Education. Allyn and Bacon A viacom Company 160 Gould Street Needham Heights,MA 02194.

Lickona, T. (2009). Educating For Character: How Our Schools Can Teach Respect and Responsibility. Bantam.Books.

Novianti, N., \& Munir, S. (2017). Nilai-Nilai Religius dalam Novel "Bulan Terbelah di Langit Amerika" Karya Hanum Salsabiela Rais dan Rangga Almahendra. Jurnal Literasi, 1(2), 73-81. http://ejournal.iaiibrahimy.ac.id/index.php/tarbiyatuna/article/view/82

Sudrajat, A. (2011). Mengapa Pendidikan Karakter. Jurnal Pendidikan Karakter, I(1), 48-49. https://doi.org/10.21831/jpk.v1i1.1316 
Suryaman, M. (2010). Pendidikan Karakter Melalui Pembelajaran Sastra. Jurnal Cakrawala Pendidikan, 1(3), 112-126. https://doi.org/10.21831/cp.v1i3.240

Tabi'in, A. (2017). Menumbuhkan Sikap Peduli Pada Anak Melalui Interaksi Kegiatan Sosial. IJTIMAIYA: Journal of Social Science Teaching, 1(1). https://doi.org/10.21043/ji.v1i1.3100

Umam, A. (2013). Pentingnya Memahami Sikap Terhadap Membaca Pada Siswa Dalam Pembelajaran Bahasa. English Education: Jurnal Tadris Bahasa Inggris IAIN Raden Intan, 5(1), 79-99.

Wibowo, M. A. (2017). Penanaman Karakter Nasionalis Religius Melalui Kurikulum Terintegrasi Pesantren Pada Peserta Didik Di SMK Syubbanul Wathon Tegalrejo Magelang. https://lib.unnes.ac.id/31839/ 